\title{
RANCANG BANGUN APLIKASI SISTEM PERENCANAAN DAN PENCATATAN ANGGARAN BIAYA KELUARGA MENGGUNAKAN METODE BUDGETING
}

\author{
Muji Sukur ${ }^{1}$, Purwaningtyas², Imam Husni Al Amin ${ }^{3}$ \\ ${ }^{1,2,3}$ Fakultas Teknologi Informasi, Universitas Stikubank \\ email: ${ }^{1}$ muji.sukur@gmail.com, ${ }^{2}$ diba_ian@yahoo.com, ${ }^{3}$ pakimam.husni@gmail.com
}

\begin{abstract}
Abstrak
Setiap keluarga menginginkan kondisi keuangan yang sehat, keuangan keluarga dinyatakan sehat kalau pengeluaran berbanding lurus dengan pemasukan. Untuk mencapai kondisi keuangan yang sehat diperlukan suatu perencanaan dan pencatattan keuangan yang baik. Dengan perencanaan dan pencatatan keuangan yang baik akan dapat mengontrol dan mengevaluasi setiap detail pengeluaran keuangan, sehingga dapat meminimalkan pengeluaran yang kurang perlu. Setiap rumah tangga perlu melakukan perencanan keuangan yang baik agar tujuan rumah tanggga jangka pendek dan jangka panjang dapat tercapai.

Perencanaan keuangan merupakan seni pengelolaan keuangan yang dilakukan oleh individu atau keluarga untuk mencapai tujuan yang efektif, efisien, dan bermanfaat, sehingga keluarga tersebut menjadi keluarga yang sejahtera. Secara umum, aktivitas yang dilakukan adalah proses pengelolaan penghasilan untuk mencapai tujuan finansial seperti keinginan memiliki dana pernikahan, dana kelahiran anak dan lain- lain. Penghasilan kita perlu dikelola agar dapat memenuhi kebutuhan saat ini dan juga kebutuhan di masa depan.

Setiap keluarga menginginkan kondisi keuangan yang sehat, keuangan keluarga dinyatakan sehat kalau pengeluaran berbanding lurus dengan pemasukan. Untuk mencapai kondisi keuangan yang sehat diperlukan suatu perencanaan dan pencatattan keuangan yang baik. Dengan perencanaan dan pencatatan keuangan yang baik akan dapat mengontrol dan mengevaluasi setiap detail pengeluaran keuangan, sehingga dapat meminimalkan pengeluaran yang kurang perlu. Dengan demikian, rancangan aplikasi budgeting merupakan suatu alat yang membantu didalam pengendalian biaya rumah tangga karena dapat memberikan informasi bagi keluarga mengenai berhasilnya (efektivitas) setiap rencana.
\end{abstract}

Kata kunci : perencanaan keuangan, keuangan keluarga yang sehat, Aplikasi Budgeting

\section{PENDAHULUAN}

Perencanaan anggaran merupakan alat yang sudah dikenal yang dipakai dalam perencanaan dan pengawasan keuangan oleh berbagai jenis organisasi, mulai yang paling kecil yaitu rumah tangga, organisasi-organisasi kemasyarakatan, perusahaan sampai dengan negara. Masing- masing mempunyai perbedaan baik dalam tingkat formalitas maupun detail dari anggaran yang dipergunakan. Dalam suatu perusahaan besar atau lembaga pemerintah, memiliki anggaran yang tertulis dan diperinci secara mendetail yang mencakup semua tahap dari operasinya. Anggaran disusun untuk membantu manajemen dalam mengadakan perencanaan, koordinasi dan pengendalian terhadap kegiatan operasi perusahaan. Anggaran juga merupakan acuan bagi pimpinan perusahaan dalam menjalankan perusahaannya ke arah yang telah direncanakan dan sebagai alat kontrol untuk mengetahui dalam kurun waktu tertentu sampai dimana pelaksanaan sesuai dengan yang direncanakan menurut anggaran yang telah ditetapkan. Dengan menggunakan anggaran, maka kerugian- kerugian dan pemborosan keuangan dapat segera diketahui, sehingga dapat diambil tindakan koreksi dan pencegahannya untuk waktu yang akan datang.

Perencanaan keuangan merupakan seni pengelolaan keuangan yang dilakukan oleh individu atau keluarga untuk mencapai tujuan yang efektif, efisien, dan bermanfaat, sehingga keluarga tersebut menjadi keluarga yang sejahtera. Secara umum, aktivitas yang dilakukan adalah proses pengelolaan penghasilan untuk mencapai tujuan finansial seperti keinginan memiliki dana pernikahan, dana kelahiran anak dan lain- lain. Penghasilan kita perlu dikelola agar dapat memenuhi kebutuhan saat ini dan juga kebutuhan di masa depan. Kebutuhan saat ini terdiri atas pengeluaran- pengeluaran yang 
dikeluarkan saat ini. Contoh kebutuhan saat ini antara lain biaya dapur, biaya cicilan motor, biaya pulsa handphone. Sedangkan kebutuhan di masa depan terdiri atas pengeluaran- pengeluaran dikeluarkan di masa mendatang. Contoh kebutuhan di masa depan antara lain biaya pendidikan anak hingga tamat sekolah, biaya naik haji, dan biaya pernikahan anak. Kebutuhan di masa depan hampir bisa dipastikan akan terjadi namun penghasilan di masa depan tidak dapat dipastikan. Setiap manusia memiliki risiko tertimpa musibah seperti kecelakaan, kehilangan pekerjaan, kebangkrutan dan kematian. Risiko tersebut dapat mengganggu perolehan penghasilan di masa depan. Sayangnya, kita tidak dapat memastikan apakah risiko tersebut akan datang. Jikalau datang, kita juga tidak dapat memastikan kapan risiko tersebut akan menimpa. Oleh karena itu perencanaan keuangan perlu dilakukan secepatnya agar kebutuhan kita di masa depan tetap dapat terpenuhi.

Pada era kemajuan teknologi saat ini khususnya mobile phone semakin berkembang pesat. Hal ini didukung dengan pertumbuhan pengguna mobile phone yang setiap taahunnya terus meningkat. Berdasarkan badan survei eMarketer (eMarketer, Desember 2015) yaitu sebanyak 52,2 juta dari penduduk di Indonesia memiliki mobile phone dan ada 60\% diantaranya didominasi oleh Android. Dari jumlah pengguna smartphone yang banyak ini membuka peluang pengembangan teknologi ke berbagai aspek salah satunya melihat dari sistem kontrol yang berpeluang untuk dikembangkan dengan menggunakan aplikasi mobile.

Menurut Rochman Saefulloh Basyari, Surya Michrandi Nasution, Burhanuddin Dirgantara (2015, p2) saat ini smartphone menjadi salah satu kebutuhan yang tidak bisa dipisahkan dari berbagai aktifitas manusia. Dalam kehidupan masyarakat saat ini yang mobilitasnya kian tinggi, smartphone menjadi asisten pribadi yang kerap kali menjadi kebutuhan primer dalam membantu aktifitas-aktifitas manusia. Termasuk akhir-akhir ini smartphone juga digunakan sebagai alat bantu pembayaran dan pembelian tiket secara online. Hal ini menjadi bukti bahwa smartphone dapat menjadi perangkat all-in-one yang mempermudah aktifitas manusia. Selain itu kemajuan smartphone ini didukung juga dengan perkembangan perangkat keras yang memungkinkan untuk pemrograman dalam melakukan challenge (otentikasi antara mobile dan perangkat keras). Dengan kemampuan perangkat keras yang memiliki teknologi komunikasi menggunakan Wifi dan internet, hal ini memungkinkan pengguna smartphone untuk mengendalikan kerja perangkat keras yang mereka miliki dengan aplikasi mobile. Particle.io adalah perusahaan yang menyediakan perangkat keras yang memungkinkan pengembang untuk melakukan pemrograman pada platform mobile (Android dan iPhone Mobile Operating Sistem).

Perkembangan aplikasi mobile tersebut mengarah kepada Internet Of Things (IoTs) menurut Rajeev Piyare (2013, p1) dapat diartikan sebagai konektivitas yang dilakukan sehari-hari ke semua objek yang berhubungan dengan aplikasi mobile, televisi, sensor, dan aktuator (peralatan mekanis untuk menggerakkan atau mengontrol sebuah mekanisme atau sistem), contohnya seperti pintu otomatis yang menggunakan koneksi internet dimana aplikasi tersebut memiliki kecerdasan yang dapat menghubungkan komunikasi baru antara alat tersebut dengan orang lain maupun pengguna tersebut. Internet merupakan jaringan komunikasi tanpa hambatan jarak, zaman sekarang masyarakat luas sudah tidak merasa asing ketika mendengar istilah internet. Diperkirakan 2,925,249,355 orang atau 40,4\% dari jumlah penduduk dunia telah menggunakan internet, hal itu dikutip dari data World Bank pada tanggal 1 Juli 2014, dan hal tesebut selalu bertambah persentasenya tiap tahun, itu secara internasional sedangkan secara nasional jumlah pengguna internet di Indonesia bertambah sebanyak 9\% pada 2014 menjadi empat puluh dua juta orang. Ini membuat Indonesia berada di peringkat ketiga dalam daftar pertambahan pengguna internet tertinggi dunia (Palo, 2014).

Setiap keluarga menginginkan kondisi keuangan yang sehat, keuangan keluarga dinyatakan sehat kalau pengeluaran berbanding lurus dengan pemasukan. Untuk mencapai kondisi keuangan yang sehat diperlukan suatu perencanaan dan pencatattan keuangan yang baik. Dengan perencanaan dan pencatatan keuangan yang baik akan dapat mengontrol dan mengevaluasi setiap detail pengeluaran keuangan, sehingga dapat meminimalkan pengeluaran yang kurang perlu. Setiap rumah tangga perlu melakukan perencanan keuangan yang baik agar tujuan rumah tanggga jangka pendek dan jangka panjang dapat tercapai. 


\section{BUDGETING}

Ramlah Basri, 2013, Pada hasil penelitianya tentang analisis penyusunan anggaran dan laporan realisasi anggaran pada BPM- PD Provinsi Sulawesi Utara. Anggaran merupakan rencana keuangan masa datang yang mencakup harapan manajemen terhadap pendapatan, biaya, dan transaksi keuangan lain dalam masa satu tahun. Tahap penyusunan anggaran merupakan tahap yang sangat penting karena anggaran yang tidak efektif dan tidak bero rientasi pada kinerja justru bisa menggagalkan programyang telah disusun sebelumnya.Tujuan penelitian ini untuk mengetahui proses penyusunan anggaran dan laporan realisasi anggaran pada BPM - PD Provinsi Sulawesi Utara. Penyusunan anggaran pada organisasi sektor publik dapat membantu mewujudkan akuntabilitas Laporan Realisasi anggaran menyajikan ikhtisar sumber, alokasi, dan pemakaian sumber daya ekonomi yang dikelola oleh pemerintah daerah yang menggambarkan perbandingan antara anggaran dan realisasinya dalam satu periode pelaporan.Metode yang digunakan adalah metode deskriptif yaitu dengan mengumpulkan data penelitian dari objek penelitian dan literature lainnya.

Fadjar Harimurti, 2008, Penyusunan anggaran merupakan proses pembuatan rencana kerja dalam rangka waktu satu tahun, yang dinyatakan dalam satuan moneter. Penyusunan anggaran sering diartikan sebagai perencanaan laba (proft planing). Dalam perencanaan laba, manajemen menyusun rencana operasional yang implikasinya dinyatakan dalam laporan laba rugi jangka pendek dan jangka panjang, neraca kas dan modal kerja yang diproyeksikan dimasa yang akan datang.

Pada dasarnya, pengendalian mengukur kinerja dengan membandingkan hasil aktual dengan hasil yang direncanakan dan mengukur penyimpangan yang terjadi. Apabila terjadi penyimpangan harus dilihat apa penyebab dan tindakan perbaikan yang perlu diambil. Sebagai sebuah rencana tindakan, anggaran dapat digunakan sebagai alat untuk mengendalikan kegiatan organisasi atau unit organisasi dengan cara membandingkan antara hasil sesungguhnya yang dicapai dengan rencana yang telah ditetapkan. Jika hasil sesungguhnya berbeda secara signifikan dari rencana, tindakan tertentu harus diambil untuk melakukan revisi yang diperlukan terhadap rencana.

\section{PERANCANGAN SISTEM}

Sebelum suatu system dikembangkan, perlu adanya suatu rumusan dan rancangan yang jelas, menyangkut berbagai aspek sistem maupun organisasinya, sehingga dapat ditentukan sasaran dan sistem yang akan dikembangkan. Disini perlu pula dipertimbangkan semua potensi maupun hambatan yang ada di organisasi tersebut yang merupakan langkah awal dalam perkembangan sebuah sistem. Sistem baru yang akan di rancang adalah aplikasi sistem budgeting. Berikut ini adalah cara menyusun anggaran yang sangat sederhana:

1) Masukan total penghasilan setiap bulan

User harus menginputkan jumlah penghasilan yang diperoleh setiap bulan, penghasilan perbulan meliputi penghasilan tetap (gaji) dan penghasilan lain yang diterima setiap bulan.

2) Inputkan semua pengeluaran rutin setiap bulan

User diminta untuk mengidentifikasi seluruh pengeluaran rutin selama satu bulan, seperti belanja harian, uang saku sekolah, biaya listrik, air dan lain-lain termasuk tabungan bulanan.

3) Tentukan nominal pengeluaran rutin untuk semua jenis pengeluaran

Masing-masing pengeluaran rutin yang telah ditentukan pada tahap identifikasi pengeluatan ditentukan jumlah nominalnya.

4) Catat setiap pengeluaran sesuai dengan jenis pengeluaran

Setiap pengeluaran yang telah dibayarkan harus dicatat sesuai dengan jumlah dan jenis pengeluaran.

5) Periksa setiap budget pengeluaran

Setiap jenis pengeluaran akan dikontrol saldo akhirnya, hal ini dilakukan untuk memberikan kontrol untuk setiap pengeluaran agar tidak melebihi budget.

\section{a. Spesifikasi Kebutuhan}

Spesifikasi kebutuhan yang digunakan dalam perancangan aplikasi budget keluarga terdiri dari:

1) Spesifikasi Fungsional 
a) Regrister, untuk dapat mengakses aplikasi budget keluarga seorang user harus melakukan regristrasi terlebih dalulu. Regristrasi dilakukan dengan menginput nama user, nomor handphone dan email.

b) Penganggaran, system dapat digunakan untuk melakukan penganggara. Untuk melakukan penganggaran user harus menentukan jenis anggaran dan nominal untuk masing-masing anggaran.

c) Pencatatan, system dapat digunakan untuk mencatat transaksi setiap transaksi realisasi anggaran. Pencatatan sebaiknya dilakukan setiap kali terjadi pengeluaran sesuai dengan jenis anggaran masing-masing Kelas Diagram

d) Pengecekan, system dapat digunakan untuk melakukan pengecekan saldo anggaran dan jadwal pembayaran anggaran.

2) Spesifikasi Data

a) Data user, data yang perlu dibuat nama user, nomer handphone dan email

b) Data anggaran, data yang perlu dibuat kode anggaran, nama anggaran, jumlah anggaran

c) Data realisasi, terdiri dari kode anggaran, tanggal realisasi, jumlah, saldo budget

\section{b. Rancangan Sistem}

1) Use case Diagram

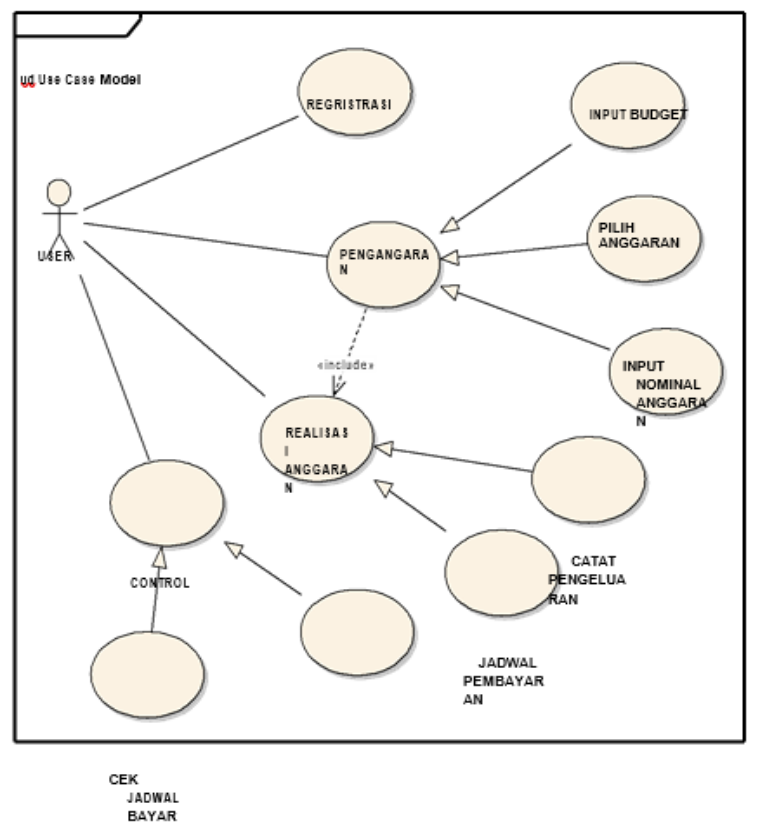

Gambar 1. Use Case Diagram Aplikasi Budgeting

Dalam rancangan system ini user harus melakukan proses registrasi atau mendaftarkan diri terlebih dahulu agar nantinya dapat bisa masuk ke dalam system. Dari hasil registrasi ini user akan mendapatkan user dan password, dengan menggunakan user dan password tersebut user dapat masuk ke dalam system. Setelah user dapat masuk ke dalam system maka user dapat melakukan penganggaran. Saat melakukan penganggaran, di dalam system terdapat tiga menu lain sebagai sub bagian dari penganggaran yaitu input budget, pilih anggaran dan input nominal anggaran. 


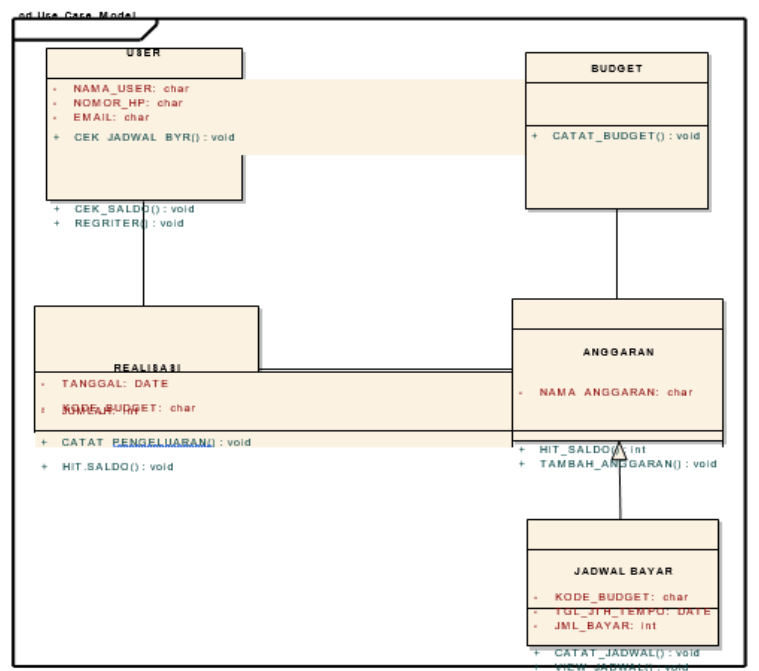

Gambar 2. Kelas Diagram

Kelas diagram pada rancangan system ini terdiri dari lima kelas yaitu kelas user, kelas budget, kelas realisasi, kelas anggaran dan kelas jadwal bayar. Pada kelas user terdapat atribut nama user, nomor hp, email dan metode cek jadwal, cek saldo, registrasi. Pada kelas budget terdapat metode catat budget. Pada kelas realisasi terdapat atribut tanggal, kode budget dan metode catat pengeluaran, hitung saldo. Pada kelas anggaran terdapat atribut nama anggaran dan metode hitung saldo, tambah anggaran. Pada kelas jadwal bayar terdapat atribut kode budget, tanggal jatuh tempo, jumlah bayar dan metode catat jadwal, tampil jadwal.

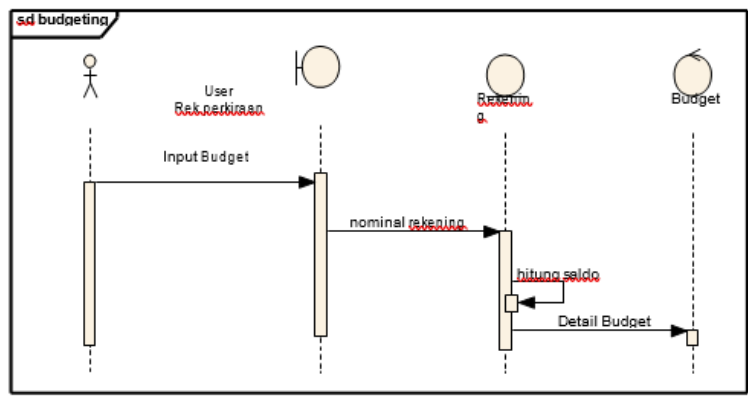

Gambar 3. Sequence Diagram Input Nominal

Sequence diagram untuk proses budgeting dimulai ketika user mulai menginput rekening perkiraan dengan sejumlah nominal masuk ke rekening. Setelah masuk rekening sejumlah nominal yang barusan dimasukkan akan dijumlah dengan sisa dana sebelumnya, sehingga akan terlihat saldo terakhir. Dari saldo terakhir akan didetailkan dalam proses budgeting.

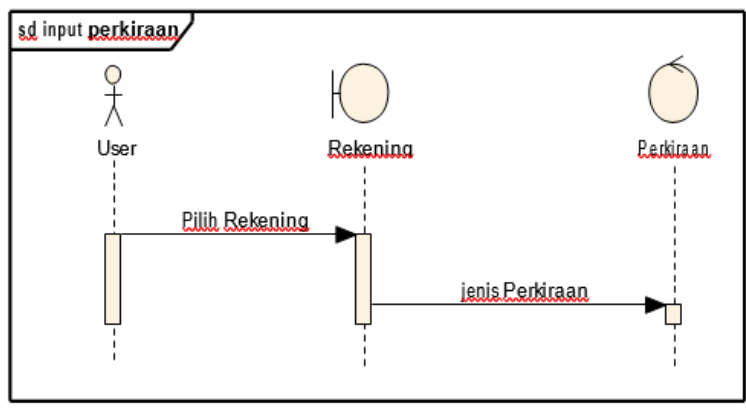

Gambar 4. Sequence Diagram Pilih Rekening 


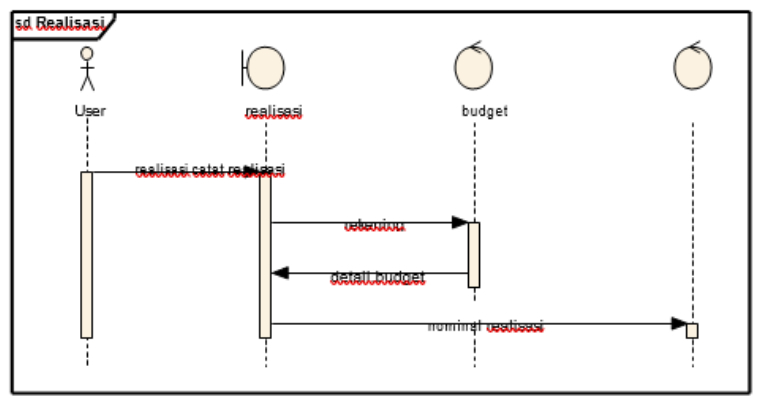

Gambar 5. Sequence Diagram Pencatatan Pengeluaran

Sequence diagram pada pencatatan pengeluaran yang dilakukan oleh user yaitu mencatat realisasi pada proses realisasi. Dari pencatatan realisasi akan dilanjutkan dengan melakukan pencatatan pada rekening dan juga pada detail budgeting. Sehingga akan terlihat sesuai dari nominal realisasi dengan kegiatan realisasinya, termasuk pada rekening dan detail budgetingnya.

\section{c. Rancangan Interfase}

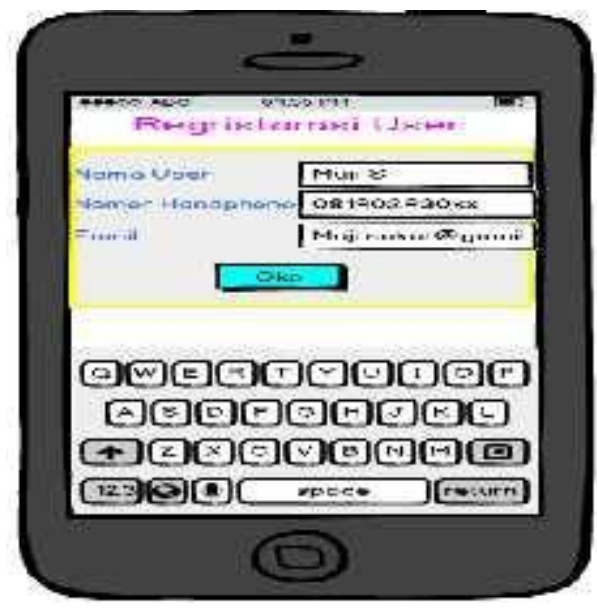

Gambar 6. Regristrasi User

User untuk dapat masuk ke dalam system harus sudah terdaftar terlebih dahulu dengan mengisi form pendaftaran dengan nama user, nomor handphone dan nama email. Sistem akan memverifikasi pendaftaran yang dilakukan oleh user dengan mengirimkan kode verifikasi melalui email. Apabila email valid maka akan dilanjutkan dengan mengisi form berikutnya termasuk pendaftaran password.

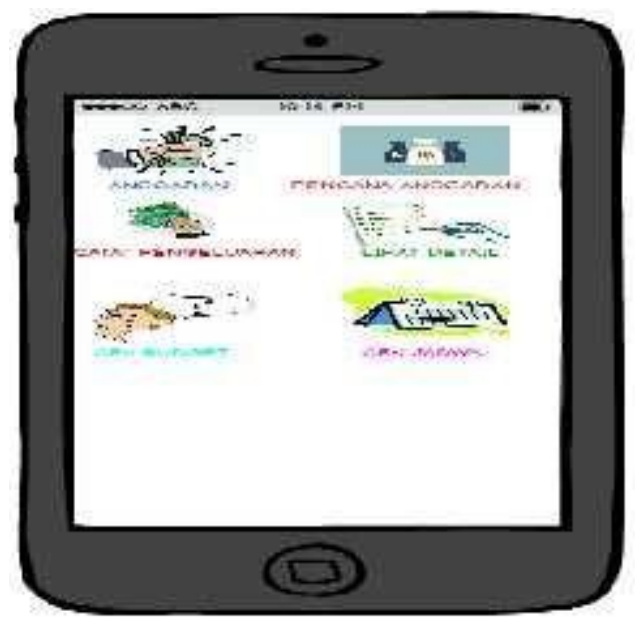

Gambar 7. Halaman Menu Utama

Rancangan halaman menu utama berfungsi untuk menampilkan semua menu yang terdapat pada system pada saat awal system mulai dijalankan. Menu utama diantara menu anggaran, menu rencana 
anggaran, pencatatan pengeluaran, melihat detail anggaran, dan sebagainya. Setiap menu yang di klik akan masuk ke sub menu - sub menu berikutnya.

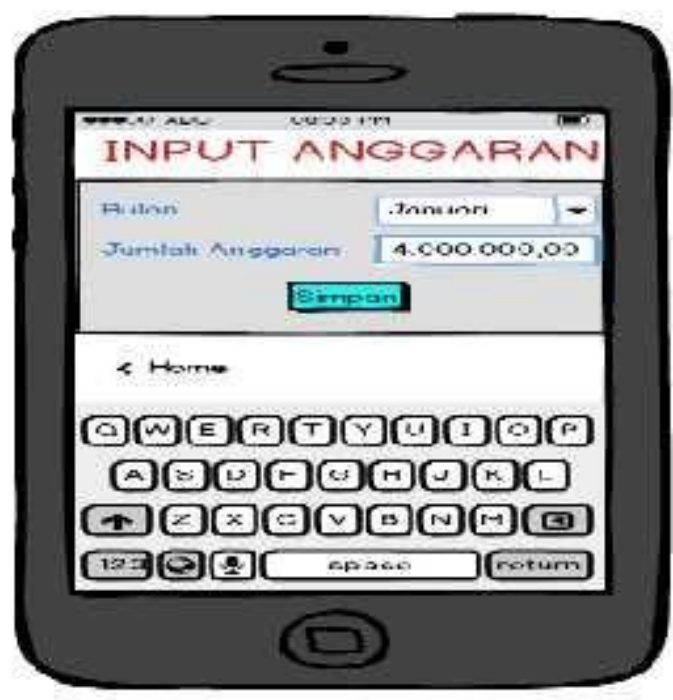

Gambar 8. Input Anggaran

Perancangan input anggaran dibuat dengan menggunakan dua pilihan input, pertama menginput bulan anggaran dan yang kedua menginput jumlah anggaran. Setelah ke dua inputan di pilih langkah berikutnya melakukan simpan dengan cara mengklik tombol simpan. Setelah inputan anggaran selesai dilakukan untuk kembali ke menu sebelumnya dengan mengklik tombol home.

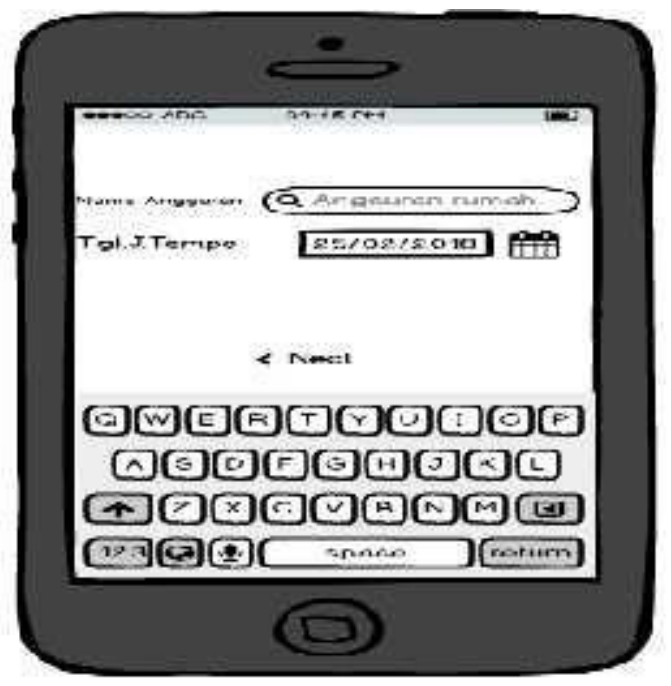

Gambar 9. Cek Jadwal Pembayaran

Perancangan cek jadwal pembayaran terdiri dari dua isian, pertama isian tentang nama anggaran, kedua tanggal jatuh tempo. Setelah semua terisi akan di perlihatkan informasi anggaran yang sudah masuk tanggal jatuh tempo. Sebaiknya anggaran yang sudah mendekati tanggal jatuh tempo sebaiknya segera direalisasikan. Apabila sudah melewati jatuh tempo maka perlu di konsultasikan ke pimpinan yang lebih berwenang untuk melalukan perubahan penjadwalan pembayaran. 


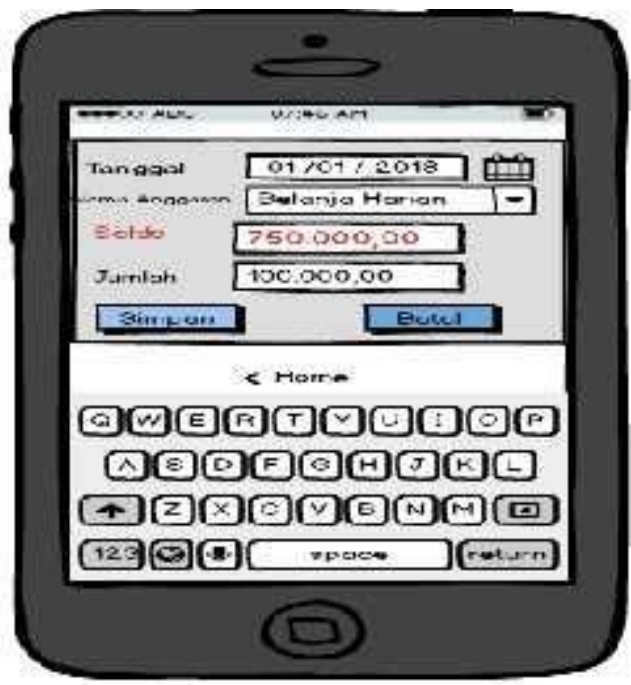

Gambar 10. Halaman Pencatatan Pengeluaran

Rancangan pencatatan pengeluaran bertujuan untuk melalukan semua pencatatan yang dilakukan per jenis kegiatan sehingga akan diketahui semua anggaran beserta kegiatannya, baik kegiatan yang beranggaran kecil hingga kegiatan yang beranggaran besar. Rancangan pencatatan pengeluaran terdiri dari empat isian pencatatan, pertama yang perlu di catat tanggal, jenis anggaran, saldo dan jumlah. Jenis anggaran diantara belanja harian, belanja mingguan, belanja bulanan. Jumlah anggaran yang diinputkan tidak boleh lebih dari saldo. Setelah semuanya terisi langkah berikutnya klik simpan. Apabila ingin dibatalkan klik batal. Dan untuk kembali ke menu sebelumnya klik tombol home.

\section{KESIMPULAN}

Adapun beberapa kesimpulan yang berhasil diperoleh dalam penelitian ini diantaranya adalah sebagai berikut :

a. Perencanaan anggaran merupakan alat yang sudah dikenal yang dipakai dalam perencanaan dan pengawasan keuangan oleh berbagai jenis organisasi, mulai yang paling kecil yaitu rumah tangga, organisasi-organisasi kemasyarakatan, perusahaan sampai dengan negara.

b. Perencanaan keuangan merupakan seni pengelolaan keuangan yang dilakukan oleh individu atau keluarga untuk mencapai tujuan yang efektif, efisien, dan bermanfaat, sehingga keluarga tersebut menjadi keluarga yang sejahtera.

c. Rancangan Aplikasi ini diharapkan dapat menjadi referensi untuk membantu keluarga dalam mencapai kondisi keuangan yang sehat, keuangan keluarga dinyatakan sehat kalau pengeluaran berbanding lurus dengan pemasukan. Untuk mencapai kondisi keuangan yang sehat diperlukan suatu perencanaan dan pencatattan keuangan yang baik.

\section{DAFTAR PUSTAKA}

[1] Aulia. 2009. Perencanaan Keuangan Keluarga (Menciptakan Surplus Anggaran dalam Keuangan Keluarga Anda). Yogyakarta : Cakrawala.

[2] Budisantoso, I \& Gunanto. 2010. Cara Gampang Mengelola Keuangan Pribadi dan Keluarga. Jakarta : P.T. Gramedia.

[3] Gunawan, Imam. 2014. Metode Penelitian Kualitatif Teori dan Praktik. Jakarta Bumi Aksara.

[4] Irawan, Agustiana. 2012. Peranan Perencanaan Keuangan Keluarga untuk Mencapai Tujuan Keuangan Keluarga dan Mengurangi Risiko Kekurangan Uang Tunai. Skripsi. Bandung : Universitas Katolik Parahyangan.

[5] Iskandar, dkk. 2010. Faktor-faktor yang Mempengaruhi Kesejahteraan Keluarga. Sumatra Utara : Universitas Sumatra Utara.

[6] Ridhotullah, Subekti \& Jauhar, Muhammad. 2015. Pengantar Manajemen. Prestasi Pustaka, Jakarta. 
[7] Stoner, J.A, F., Freeman R, E., and Gilbert Jr, D,R. 1996. Manajemen, Alih bahasa : Alexander Sindoro, Jilid I, P.T. Prenhalindo, Jakarta.

[8] Warsono. 2010. Prinsip-prinsip dan Praktik Keuangan Pribadi.Volume 13 no 2.

[9] Yoanita, Anastasia. 2009. Peranan Perencanaan Keuangan Keluarga dalam Meningkatkan Kesejahteraan Keluarga. Skripsi. Bandung : Univesitas Katolik Parahyangan. 